\title{
ENFORCEMENT OF THE EXCELSIOR RULE IN THE DISTRICT COURTS
}

The National Labor Relations Board has been concerned for many years with the problems created by the inherent advantage enjoyed by employers in gaining access to eligible voters in representation proceedings. The major difficulty has been that a labor union has no way to be certain of reaching all the employees with its arguments, whereas the employer is assured of the continuing opportunity to inform the entire electorate of his views. As a result, some employees are often completely unaware of the union's point of view at the time of the election.

To remedy this situation, the Board, in Excelsior Underwear, Inc., ${ }^{1}$ held that in all representation proceedings under the National Labor Relations Act, the employer must file with the regional director conducting the election a list containing the names and addresses of all eligible voters within seven days after the election has been ordered. ${ }^{2}$ The regional director, in turn, is required to make this information available to all parties to the proceeding.

Failure to comply with the Excelsior rule-an employer's refusal to disclose the names and addresses of his employees-is regarded as tending to interfere with prospects for a fair and free election, and thus provides a per se ground for setting aside the election. ${ }^{3}$ This sanction, although achieving compliance with the Excelsior rule in the great majority of cases, still provides the employer with a "way out." If he is willing to accept the penalty of having only a union-won election validated, he can refuse to comply with the rule.

Recently, the NLRB has sought to close this door left open to the employer by forcing compliance through the courts. Judicial enforcement has been sought under two theories: (1) that the lists can be subpoenaed as evidence under section 11 of the National Labor Relations Act, ${ }^{4}$ and (2) that an injunction can be obtained from the federal district court under section 1337 of the Judicial Code. ${ }^{5}$ Under these theories the Board has had varying success in securing specific

1156 N.L.R.B. 1236 (1966).

2 The Board's primary reason for affording union access to a list of names and addresses was to achieve a more informed electorate. Id. at 1240-42. In addition, the Board noted that access to such a list would facilitate eligibility checks for the union, and thereby reduce the number of challenges that the Board would have to resolve. Id. at $1242-43$.

3 Id. at 1240 .

429 U.S.C. $\$ 161$ (1964).

528 U.S.C. $\$ 1337$ (1964) 
performance of its rule. ${ }^{b}$ For instance, in NLRB v. Hanes Hosiery Division, ${ }^{7}$ the Fourth Circuit decided that "fairness in the elective process demands here . . . the opportunity of contesting parties to communicate their respective positions to the electorate," $s$ and that relief should be afforded under either section 11 of the NLRA or 28 U.S.C. § 1337. In NLRB v. Rohlen, ${ }^{n}$ the Seventh Circuit held that it was proper for the Board to subpoena the list as evidence which would aid in the determination of "employee group-preference." 10 However, the court declined to pass on the issue whether the district court had jurisdiction to enforce compliance with the rule under 28 U.S.C. $\S 1337$. Later, the Federal District Court for the District of New Jersey, in NLRB v. Q-T Shoe Manufacturing Co., ${ }^{11}$ refused to grant relief under either theory and held that "enforcement of the Excelsior rule can only occur after it has been properly determined by the Board that the refusal by the defendant to provide the Union with a list of its employees' names and addresses constitutes an unfair labor practice under Section 8(a) (1) of the Act . . . "12

For the purpose of this Comment it will be assumed that the Excelsior rule itself is valid. ${ }^{13}$ The only issue discussed is the propriety of enforcing the rule under either section 11 of the NLRA or 28 U.S.C. $\S 1337$.

6 As of July, 1968, eleven courts have passed on actions brought by the Board for subpoena enforcement or a mandatory injunction in aid of the Excelsior rule. Four courts have granted relief under both theories. NLRB v. Hanes Hosiery Div., 384 F.2d 188 (4th Cir. 1967), cert. denied, 390 U.S. 950 (1968); Swift \& Co. v. Solien, 274 F. Supp. 953 (E.D. Mo. 1967) ; NLRB v. British Auto Parts, Inc., 266 F. Supp. 368 (C.D. Cal. 1967) ; NLRB v. Wolverine Indus. Div., 54 CCH Lab. Cas. f 11,658 (E.D. Mich. 1966). Four courts enforced the Board's subpoena but did not pass on the question whether an injunction could issue. NLRB v. Rohlen, 385 F.2d 52 (7th Cir. 1967); NLRB v. Cone Mills Corp., $58 \mathrm{CCH}$ Lab. Cas. II 12,861 (D. S.C. July 17, 1968); NLRB v. Teledyne, Inc., 56 CCH Lab. Cas. $\Uparrow 12,229$ (N.D. Cal. Oct. 11, 1967); NLRB v. Beech-Nut Life Savers, Inc., 274 F. Supp. 432 (S.D. N.Y. 1967). Two courts have denied relief under either theory. NLRB v. Q-T Shoe Mfg. Co., $279 \mathrm{~F}$. Supp. 1 (D. N.J. 1968) ; NLRB v. Montgomery Ward \& Co., 54 CCH Lab. Cas. II 11,659 (M.D. Fla. Jan. 13, 1967). One circuit court, reversing the district court's order upholding the Board's subpoena, found that the Excelsior rule itself was invalid because it was not promulgated in accordance with the notice and publication requirements of the Administrative Procedure Act, 5 U.S.C.A. \$\$ 552, 553 (1967). WymanGordon Co. v. NLRB, 58 CCH Lab. Cas. II 12,750 (1st Cir. June 12, 1968).

7384 F.2d 188 (4th Cir. 1967).

8 Id. at 191.

8 385 F.2d 52 (7th Cir. 1967).

$10 \mathrm{Id}$. at 57.

11279 F. Supp. 1 (D. N.J. 1968).

12 Id. at 8.

13 This assumption has been denied recently by the court in Wyman-Gordon Co. v. NLRB, $58 \mathrm{CCH}$ Iab. Cas. $\pi 12,750$ (1st Cir. June 12, 1968), where it was held that the Excelsior rule "was promulgated in disregard of the notice and publication requirements of the Administrative Procedure Act, 5 U.S.C.A. \$§ 552, 553 [1967]" and therefore would not be enforced. Id. at 21,806. This argument has been made to other courts but has been rejected. NLRB v. Q-T Shoe Mfg. Co., 279 F. Supp. 1, 5 (D. N.J. 1968) ; NLRB v. Beech-Nut Life Savers, Inc., 274 F. Supp. 432, 438 (S.D. N.Y. 1967). 


\section{The Board's Power to Subpoena the Lists of Names and Addresses Under Section 11 of the National Labor Relations Act}

Section 11(2) of the National Labor Relations Act permits the Board to issue, and the district courts to enforce, subpoenas requiring a ". . . person to appear before the Board, its members, agents, or agency, there to produce evidence if so ordered, or there to give testimony touching the matter under investigation or in question." 14

Historically, courts had been slow to recognize the broad power of administrative agencies to subpoena material. At the beginning of the century, they applied to administrative agencies the same rules which had limited their own powers of investigation. For example, in F.T.C. v. American Tobacco Co. ${ }^{15} \mathrm{Mr}$. Justice Holmes condemned the Federal Trade Commission's attempt to exercise its subpoena powers on the ground that "fishing expeditions" into private records were contrary to the fourth amendment. However, as administrative regulation expanded, the need for broad investigatory powers became apparent. In 1950, in United States v. Morton Salt Co., ${ }^{\mathbf{1 6}}$ the Court

14 National Labor Relations Act [hereinafter cited as NLRA] §11, U.S.C. § 161 (1964) :

For the purpose of all hearings and investigations which, in the opinion of the

Board, are necessary and proper for the exercise of the powers vested in it by

section 9 and section 10

(1) The Board, or its duly authorized agents or agencies, shall at all reasonable times have access to, for the purpose of examination, and the right to copy any evidence of any person being investigated or proceeded against that relates to any matter under investigation or in question. The Board, or any member thereof, shall upon application of any party to such proceedings, forthwith issue to such party subpenas requiring the attendance and testimony of witnesses or the production of any evidence in such proceeding or investigation requested in such application ... [T] [Te Board shall revoke such subpena if in its opinion the evidence whose production is required does not relate to any matter under investigation, or any matter in question in such proceedings ....

(2) In case of contumacy or refusal to obey a subpena issued to any person, any district court of the United States ... within the jurisdiction of which said person guilty of contumacy or refusal to obey is found or transacts business, upon application by the Board shall have jurisdiction to issue to such person an order requiring such person to appear before the Board, its member, agents, or agency, there to produce evidence if so ordered, or there to give testimony touching the matter under investigation or in question.

15264 U.S. 298, 305-06 (1924) (F.T.C. sought to subpoena records, memoranda and correspondence. The subpoenas were requested pursuant to a Senate resolution passed August 9, 1921, directing the Commission to investigate the tobacco industry.)

It should be noted that the subpoena power granted the FTC is very similar in scope to that given the NLRB by $\S 11$. See StafF of SENATE Comm. on Ev. \& Labor, 74tr Cong., Ist Sess., Comparison of S. 2929 and S. 1958, at 40 (Comm. Print 1935), reproduced in 1 Legislative History of the National Labor Relations Act of 1935 , at 1319,1367 (1949).

16338 U.S. 632 (1950). In this case, the F.T.C. had ordered Morton Salt Co. and others to cease and desist from certain trade practices. The corporations followed the order and reports of compliance were filed and accepted. Subsequently the Commission ordered the corporations to file special reports to show continuing compliance with the decree. The Court stated that "[e]ven if one were to regard the request for information in this case as caused by nothing more than official curiosity, nevertheless law enforcing agencies have a legitimate right to satisfy themselves that corporate behavior is consistent with law and the public interest." Id. at 652 . 
was willing to reject objections based on the fourth and fifth amendments and enforced the Federal Trade Commission's request for documents even though it was such a "fishing expedition."

The broad power of administrative agencies to investigate does not imply, however, an unlimited power to compel the production of any and all information. The purpose of an investigation must be to enable the investigating party to decide some question properly before it. Information demanded by subpoena must be sought for the purpose of answering that question. ${ }^{17}$

In its memoranda before the district courts, the Board states that: The representation proceeding conducted pursuant to Section 9 of the Act . . . is clearly an "investigation" within the meaning of Section $11 . .^{18}$

It then goes on to argue that the Excelsior list, by insuring a more informed and reasoned choice, is relevant to the final outcome of that investigation. In support of this proposition the Board cites four cases. ${ }^{19}$

None of the four is persuasive, and only two are even relevant. ${ }^{20}$ Inland Empire District Council v. Millis ${ }^{21}$ does say clearly that the

17 See id.: Information must be supplied "if the inquiry is within the authority of the agency, the demand is not too indefinite and the information sought is reasonably relevant." (emphasis added). Cf. Oklahoma Press Publishing Co. v. Walling, 327 U.S. 186, 209 (1946) ; Endicott Johnson Corp. v. Perkins, 317 U.S. 501, 509 (1943).

18 E.g., Memorandum for Plaintiff at 4 n.2, NLRB v. British Auto Parts, Inc., 266 F. Supp. 368 (C.D. Cal. 1967); Memorandum for Plaintiff at $4 \mathrm{n.2}$, NLRB v. Montgomery Ward \& Co., 54 CCH Lab. Cas. $\mathbb{1 1}$ 11,659 (M.D. Fla. Jan. 13, 1967); Memorandum for Plaintiff at 4 n.2, NLRB v. Wolverine Indus. Div., 54 CCH Lab. Cas. $\pi 11,658$ (E.D. Mich. 1966). The footnote is identical in each of the memoranda above and, since it has gone unchallenged, is probably standard form for all memoranda prepared by the General Counsel.

10 Lewis v. NLRB, 357 U.S. 10 (1958); Inland Empire Dist. Council v. Millis, 325 U.S. 697 (1945); NLRB v. Duval Jewelry Co., 243 F.2d 427 (5th Cir. 1957), aff'd, 357 U.S. 1 (1958) ; Kearney \& Trecker Corp. v. NLRB, 209 F.2d 782 (7th Cir. 1953).

20 The others are easily dismissed. In NLRB v. Lewis, 357 U.S. 10 (1958), the question whether an investigation was being conducted by the Board in a representation proceeding was not presented. Instead, Lewis dealt with subpoenas issued during a $\$ 8$ [29 U.S.C. $\$ 158$ (1964)] unfair labor practice investigation. Thus the case lends no support to the Board's argument-that the Excelsior list can be subpoenaed because the entire representation proceeding under $\$ 9$ (c), 29 U.S.C. 159(c) (1964), is an investigation - since that section was simply not involved in the Lewis case.

In the other case cited, Kearney \& Trecker Corp. v. NLRB, 209 F.2d 782 (7th Cir. 1953), the Seventh Circuit held that information used by the Board to decide whether to hold a hearing on the question of representation was not part of the "record in the proceeding." Under \$9(d) of the Act, 29 U.S.C. \$159(d) (1964), the record of an investigation made pursuant to $\S 9$ (c) is to be included in the transcript of the entire record required to be filed when a court reviews a Board order in an unfair labor practice proceeding. The employer argued that "each step taken under 9 (c) . . . [was] part of the investigation" and, therefore, information relied upon by the Board in making its decision whether to hold a hearing was part of the record. Id. at 786. The court's decision, rejecting the employer's argument, lends no authority to the proposition advanced by the Board in cases involving subpena of the Excelsior lists. Since the court decided that the only record the Board had to make was a transcript of the hearing on the question of representation, it is implicit that this is the only step under $\$ 9$ (c) that the court considered an "investigation." Whether the Board was conducting an investigation after it determined that such a question existed-a point crucial to the Board's argument here-was in no way involved in the case.

21325 U.S. 697 (1945). 
entire representation proceeding, up to certification of (or refusal to certify) the union as bargaining representative, is an "investigation." 22 But Inland Empire, decided in 1945, was interpreting section 9(c) of the original Wagner Act. ${ }^{23}$ Under that section, the Board had discretion to "take a secret ballot of the employees, or utilize any other suitable method to ascertain such representatives." 24 As the Court noted, this section allowed the Board to use the results of the election as evidence tending to show employee desires. ${ }^{25}$ But the Board was not bound by the election results, and could disregard them if it so chose; it was to ascertain the proper bargaining representatives by whatever method it found suitable. ${ }^{26}$ The ultimate fact of representation was a question for the Board to determine. Therefore, the entire proceeding up to certification was properly deemed an "investigation."

The Taft-Hartley Act of 1947, however, amended section 9(c) to make an election mandatory once a question of representation was found to exist. ${ }^{27}$ As the House Minority Report pointed out, the Board's function was merely to determine whether such a question existed; if it did, the election was to be held and the results certified. ${ }^{28}$ The Board's "investigation" therefore ends upon its determination that a question of representation exists, and the Board's reliance on Inland Empire is misplaced.

NLRB v. Duval Jewelry Co., ${ }^{29}$ also relied on by the Board, cannot be distinguished on the same grounds: it was decided in 1958. There, the Court upheld the Board's power to subpoena evidence during a representation proceeding. But the Court's reasoning is consistent with the argument just made, for the subpoena in Duval was issued pursuant to an investigation whether a question of representation existed. ${ }^{30}$ Until that question has been decided, an "investigation" is admittedly in progress; the Excelsior list cases, however, all involve information demanded after that question has been decided (affirmatively) and an election ordered. Duval does not speak to this issue.

As an alternative to the above, it might be argued that the information is relevant to the Board's investigation of eligibility. In a representation proceeding the Board must determine the appropriate bargaining unit ${ }^{31}$ and whether a question of representation exists. ${ }^{32}$ As a necessary corollary to these questions, the Board must also determine

22 See id. at 707.

23 Act of July 5, 1935, ch. 372, §9(c), 49 Stat. 453.

$24 I d$. (emphasis added).

25325 U.S. at 707.

26 Id.

27 Act of June 23,1947 , ch. 120, \$9(c), 61 Stat. 144.

28 See H.R. REP. No. 245, 80th Cong., 1st Sess. (1948) (minority report), reproduced in 1 Legislative History of the Labor-Managentent Relations Act of 1947 377 (1948).

29357 U.S. 1 (1958), aff'g 243 F.2d 427 (5th Cir. 1957).

30 See id. at $2-4$.

31 NLRA § 9(b), 29 U.S.C. \$159(b) (1964).

32 NLRA § 9 (c), 29 U.S.C. \$ 159 (c) (1964). 
which employees are eligible to vote. Prior to Excelsior an employer, shortly before the election, was required to supply the Board with a list of names of the employees claimed by him to be eligible to vote. ${ }^{33}$ In Excelsior the Board, in addition to holding that the list was necessary for an informed electorate, reasoned that its new rule-by making both the names and addresses available early in the election proceedingwould further aid the union in ascertaining the eligibility of voters. ${ }^{34}$ The Board did not claim that the list would be helpful for its own use in determining eligibility. Rather, it was thought that the availability of the list would reduce the number of eligibility challenges the union would otherwise make and thereby reduce the number of Board investigations into the merits of such challenges. Under this reasoning, the Board would not demand the names and addresses for its own use, but would seek to act "as a mere conduit for the union." ${ }^{35}$

Nowhere do Sections 11(1) and 11(2) of the Act authorize the Board to use its investigatory and subpoena powers for the sole purpose of transmitting information to certain parties. ... The plain language of Section 11(1) of the Act would appear to indicate that there must be some independent use made by the Board itself of evidence obtained pursuant to its investigatory powers. ${ }^{36}$

No case can be found where a subpoena was used for the sole purpose of transferring information to another party; the cases upholding the Excelsior list are decided on other grounds. Although the list of names which the employer was required to supply under the rule before Excelsior was available to the union for its use in making challenges, this list was nevertheless subpoenaed for the Board's own use in determining eligibility. ${ }^{37}$

Even if the Excelsior list could properly be subpoenaed merely to aid the union in making challenges, however, that fact should not be determinative in the present cases. The Board could properly subpoena the Excelsior list for a number of purposes- to make independent use of it in determining eligibility, to conduct an election by mail, ${ }^{38}$ or perhaps even to determine the appropriate bargaining unit and whether a question of representation exists. But it is clear that the list of names and addresses is not being subpoenaed here to aid in the determination of eligibility or of any other question. The Board is subpoenaing the lists to ensure equal communication of the election issues.

33 See NLRB v. Friedman, 352 F.2d 545 (3d Cir. 1965).

34 Excelsior Underwear, Inc., 156 N.L.R.B. 1236, 1242-43 (1966).

35 NLRB v. Q-T Shoe Mfg. Co., 279 F. Supp. 1, 6 (D.N.J. 1968).

$36 I d$. at 6-7.

37 See Cudahy Packing Co. v. NLRB, 117 F.2d 692 (10th Cir. 1941).

38 See NLRB v. Groendyke Trans., Inc., 372 F.2d 137, 141-42 (10th Cir. 1967). 
The opinion in Excelsior must be read in the context of the history which led up to it. Excelsior is the latest in a series of cases which attempt to deal with the problem of inequality of communication in election proceedings. ${ }^{39}$ Aiding the union in handling challenges was not the reason for the rule, but merely an additional advantage which might be effected by it. The purpose of the Excelsior rule, and the purpose of the Board here in requesting the lists, is not to determine eligibility, but to insure that the final question of representation is determined "under conditions designed to promote a 'free and reasoned' employee choice." 40

In NLRB v. Hanes Hosiery Division, ${ }^{41}$ the Fourth Circuit, in reversing the district court and granting enforcement of the Board's subpoena, stated:

The information sought by the Director in this case was in our judgment "evidence" of a "matter under investigation or in question" as contemplated by Section 11 of the Act, 29 U.S.C. $\S 161$. One of the powers vested in the Board was the certification of employee representatives . . . . The union's petition for the election invoked this power and engendered, as a reasonable incident, inquiry of who were the prospective balloters and the most advisable means of achieving a just understanding expression of their preference. ${ }^{42}$

The court's reasoning is specious. The list of names and addresses was not subpoenaed to aid in the inquiry of who were the prospective balloters. ${ }^{43}$ Nor was it subpoenaed to aid in the inquiry of the most advisable means of achieving a just and understanding expression. That inquiry had already been held and a determination made in the Excelsior case itself. There the Board declared that union access to the names and addresses of employees was necessary to a fair and reasoned employee choice. The Board now seeks to subpoena these names and addresses not to discover the most advisable means of achieving a just and understanding expression, but rather to enforce what they have already decided is the best means for achieving such an expression.

39 See, e.g., NLRB v. United Steelworkers of America, 357 U.S. 357 (1958); NLRB v. Babcock \& Wilcox Co., 351 U.S. 105 (1956); Republic Aviation Corp. v. NLRB, 324 U.S. 793 (1945); NLRB v. S\&H Grossinger's, Inc., 372 F.2d 26 (2d Cir. 1967) ; General Elec. Co., 156 N.L.R.B. 1247 (1966); May Dep't Stores Co., 136 N.L.R.B. 797 (1962); Livingston Shirt Corp., 107 N.L.R.B. 400 (1953); Peerless Plywood Co., 107 N.L.R.B. 427 (1953). See generally, Comment, 80 HARv. L. REv. 459 (1966).

40 Brief for Appellee at 46, NLRB v. Rohlen, 385 F.2d 52 (7th Cir. 1967).

41384 F.2d 188 (4th Cir. 1967), cert. denied, 390 U.S. 950 (1968).

42384 F.2d at 191.

43 In Hanes the employer even offered the list of names and addresses for the Board's own use in determining eligibility. Id. 
In sum, as the courts have properly recognized, Congress intended the National Labor Relations Board to have a broad subpoena power. But this broad subpoena power is for the purpose of investigation, not as a means of enforcing Board policy and regulating conduct. The Board may not use an investigation as a guise for enforcing its policy:

[I] t was certainly not the intention of Congress under Section $11(2)$ to confer jurisdiction upon federal courts for the disguised purpose of enforcing the Board's rules of decision. ${ }^{44}$

\section{The Granting of an Injunction Under 28 U.S.C. $\$ 1337$}

As an alternative to its request for subpoena enforcement, the Board has asked the district courts for a mandatory injunction under section 1337 of the Judicial Code. This section confers upon the district courts "jurisdiction of any civil action or proceeding arising under any Act of Congress regulating commerce . . . ."45

On its face, section 1337 would seem to sustain jurisdiction in the district courts. But the section is not to be read so broadly. ${ }^{46}$ The National Labor Relations Act has set up complex procedures for review ${ }^{47}$ of Board orders. ${ }^{48}$ Normally, these procedures are not to be circumvented by resort to the federal courts except as provided by the Act. ${ }^{49}$ The Board has argued here that an injunction is necessary to effectuate its statutory power to control the conduct of elections. ${ }^{50}$ But this is by no means clear. If an employer's refusal to abide by the Excelsior rule amounts to an unfair labor practice, the obvious intent of the Act is that the normal procedures for restraining such

44 NLRB v. Q-T Shoe Mfg. Co., 279 F. Supp 1 (D. N.J. 1968).

4528 U.S.C. $\$ 1337$ (1964) :

The district courts shall have original jurisdiction of any civil action or proceeding arising under any Act of Congress regulating commerce or protecting trade and commerce against restraints and monopolies.

46 See, e.g., Firestone Tire \& Rubber Co. v. Samoff, 365 F.2d 625, 627 (3d Cir. 1966) ; cf. Boire v. Greyhound Corp., 376 U.S. 473, 480 (1964). But see Capitol Serv., Inc. v. NLRB, 347 U.S. 501, 504 (1954).

47 Arguably, the suit is 'not one to 'review' in the sense of that term as used in the Act, a decision of the Board ...." since the Board is instituting the action, and therefore comes within the principle of Leedom v. Kyne, 358 U.S. 184, 188 (1958), from which the above language is taken. This, however, turns the case on its head. In Leedom, review was allowed out of the normal sequence "to strike down an order of the Board made in excess of its delegated powers and contrary to a specific prohibition in the Act." Id. Not surprisingly, the Board has made no such claim here.

48 See generally Leedom v. Kyne, 358 U.S. 184, 191-201 (1958) (Brennan \& Frankfurter, JJ., dissenting).

49 Twice, each case "characterized by extraordinary circumstances," Boire v. Greyhound Corp., 376 U.S. 473, 479 (1964), the Supreme Court has permitted district court review of orders in certification proceedings. The two cases are McCulloch v. Sociedad Nacional, 372 U.S. 10 (1963) (international ramifications) and Leedom v. Kyne, 358 U.S. (1958) (discussed in note 47 supra).

50 The memoranda in the district courts are virtually identical. Probably the besttyped is Memorandum in Support of Complaint for Order Compelling Production of Records at 11-14, NLRB v. Montgomery Ward \& Co., 54 CCH Lab. Cas. $\pi 11,659$ (M.D. Fla. Jan. 13, 1967). 
practices be followed. On the other hand, if the refusal to provide the lists does not amount to an unfair labor practice, it is questionable whether the Board is entitled to enforce compliance at all..$^{51}$

For a number of reasons, the Board has sought to avoid determining whether noncompliance with the Excelsior rule is an unfair labor practice. ${ }^{52}$ By so doing the Board has attempted to circumvent the statute. If the requested subpoenas were enforced or the injunctions issued, the NLRB not only would be able to enforce its election rule exactly as if noncompliance were an unfair labor practice, but also would be able to avoid determining if such noncompliance is indeed an unfair labor practice. Thus, if successful, the Board would be able to bypass all the requirements and time involved in finding conduct an unfair labor practice by merely setting an election rule and then enforcing it in the district court through an injunction. ${ }^{53}$

This danger is most clearly demonstrated in the very case which established the Board's power to set standards of conduct and to invalidate an election for the breach of those standards, even though such a breach might not amount to an unfair labor practice. In General Shoe Corp. ${ }^{54}$ the NLRB set aside an election because the employer had engaged in noncoercive anti-union speeches. Such conduct was protected from being declared an unfair labor practice by section $8(\mathrm{c})$ of

51 See notes 52-57 infra and accompanying text.

52 There is probably one principal reason why the Board has refused to seek enforcement of Excelsior as an unfair labor practice. The Excelsior rule applies to every election case. Failure to comply with the rule provides a per se ground for setting aside the election. Even if the Board could find that an employer's refusal to reveal the names and addresses of his employees was an unfair labor practice in one case, it is doubtful whether the Board could hold that such noncompliance would be an unfair labor practice in every case. Whether a presumption exists or not, interference, restraint and coercion are not elements which can be predetermined; they must be sought in the particular facts of the particular case. See text accompanying notes 56-57 infra. In some election proceedings, for instance, where the bargaining unit is very small and the union knows the names and addresses of all the eligible voters, it would be very difficult to find that the absence of the Excelsior list interfered with the employees' $\S 7$ rights. Since noncompliance with the Excelsior rule might not be an unfair labor practice per se, an employer might violate the rule in the hopes that the particular circumstances surrounding his action would make his noncompliance legal. The need in every case to litigate the issue whether the absence of the list did, indeed, interfere with the employees' rights would make enforcement of the rule so unwieldly and time-consuming as to completely undermine its effectiveness.

It might also be noted that in refusing to supply the Excelsior list, the employer is guilty only of inaction. There may be some difficulty in stating that a person has engaged in interference, restraint or coercion, when he has not acted at all. See Wyman-Gordon Co. y. NLRB, 58 CCH Lab. Cas. II 12,750 at 21,809 (1st Cir. June 12, 1968) (dissenting opinion by Coffin, C.J.).

53 Enforcing the subpoena or upholding issuance of an injunction in the present actions would also drastically limit the scope of judicial review. If the court decides that the subpoena is within the Board's statutory authority, that is, if it is a proper subpoena under the statute, then the subpoena must be enforced and review of the Board's decision is precluded. Likewise, if the court decides that an injunction is necessary to effectuate the Board's power to control election conduct, then the injunction must be issued and the scope of the court's review is finished. Such decisions would allow the Board to establish a per se rule for judicial enforcement of Excelsior, and would prevent the courts from making their normal inquiry into whether there was sufficient evidence that the employer's conduct did, in fact, interfere with or coerce the employees in the exercise of their $\$ 7$ rights.

5477 N.L.R.B. 124 (1948). 
the National Labor Relations Act, which insures employers as well as unions the right of free speech in an election campaign. ${ }^{55}$ If the Board could promulgate an election rule prohibiting such speech and could enforce that rule by injunction, it would be able to bring about exactly the result which section 8 (c) was designed to prevent.

The area of employer no-solicitation and no-distribution rules provides a further illustration of the extent to which granting the Board's request for an injunction in the present cases would improperly expand the Board's power in other cases. The courts have held that the question whether the employer's no-solicitation or nodistribution rule constitutes an unfair labor practice is not subject to any "mechanical answers" but must be answered by balancing the right of the employer to control his plant against the right of the employees to organize. For example, in NLRB v. United Steelworkers of America, ${ }^{56}$ the Supreme Court held that whether the enforcement of a valid no-solicitation rule by an employer who is at the same time engaging in anti-union solicitation is an unfair labor practice cannot be answered by any predetermined test, but rather must be decided according to the facts of each particular case. However, under the Hanes Hosiery rationale, this requirement can be easily and effectively avoided. The Board could establish an election rule that the enforcement of a no-solicitation rule by an employer who is at the same time engaging in anti-union solicitation would provide a per se ground for setting aside the election. If an employer refused to obey this rule, the Board would be entitled to an injunction as necessary to effectuate its clear power to control election conduct. ${ }^{57}$ Thus the Board would be permitted to avoid balancing the respective rights of

55 NLRA § 8(c), 29 U.S.C. \$158(c) (1964) :

The expressing of any views, argument, or opinion, or the dissemination thereof, whether in written, printed, graphic, or visual form, shall not constitute or be evidence of an unfair labor practice under any provision of [the NLRA], if such expression contains no threat of reprisal or force or promise of benefit.

The General Shoe doctrine itself allows the Board to frustrate the unfair labor practice requirements of the Act. By overturning an election because of noncoercive employer speech, the Board is effectively discouraging precisely the kind of conduct \& (c) was designed to protect.

68357 U.S. 357 (1958).

57 As pointed out in the text, granting the injunction in the present cases would improperly expand the Board's power in other cases. However, this increase in power would not be as far-reaching if the relief granted the Board were limited to enforcement of the subpoena under NLRA \$11, 29 U.S.C. \$161 (1964). For an expanded subpoena power to be useful to the Board, there would have to be something to subpoena. Thus, the subpoena would be useless both in preventing the employer from speaking in the Genteral Shoe situation and in enforcing a rule against no-solicitation rules.

However, even if granting the requested subpoenas would not greatly expand the Board's power in other situations, it would greatly expand its power to compel employers to furnish unions with lists of employees. Because a list can be subpoenaed, the Board could restrain violation of the $E x c e l s i o r$ rule just as though its violation were an unfair labor practice, even though the Board made no finding under the unfair labor practice sections of the Act. 
employees and employer according to the particular circumstances merely by avoiding the entire question whether the no-solicitation or no-distribution rule is an unfair labor practice.

\section{Conclusion}

Congress has set up five specific ways in which the NLRB can come before the federal courts. ${ }^{58}$ Aside from enforcing a subpoena, the courts can permanently restrain conduct at the Board's instance where that conduct is found to "interfere, restrain, or coerce employees in the exercise of the rights guaranteed by Section $7 . . . "{ }_{50}$ Even if Congress did intend the Board to have control of election conduct, it did not intend the Board to have the power to set election rules enforceable by a district court. Such a result would upset the entire enforcement procedure of the Act and make unfair labor practice findings unnecessary. Congress intended that neither "the National Labor Relations Board [nor] the Courts should be given any blanket authority to prohibit whatever labor practices . . . in their judgment are deemed to be unfair." "Bo Only if refusal to comply with the Excelsior rule is found to constitute an unfair labor practice-to interfere with, restrain or coerce the employees' section 7 rights-should the employer be ordered by a court to submit the list. And such an order should only come from a circuit court enforcing a Board order.

58 Judicial intervention is authorized by the following sections of the National Labor Relations Act:

1. NLRA $\$ 10(j), 29$ U.S.C. $\$ 160(j)$ (1964), gives the Board power to petition a district court for temporary injunctive relief after the issuance of a complaint in an unfair labor practice proceeding.

2. Where certain specified unfair labor practices are involved, the Board has limited recourse to the courts even before a complaint has been issued. NLRA $\S 10(1), 29$ U.S.C. $\$ 160(1)$ (1964).

3. NLRA $\S 10(f), 29$ U.S.C. $\$ 160(f)$ (1964), provides that courts of appeals of the United States are to be the only forums in which Board orders may be reviewed as of right.

4. The Board may petition the courts of appeals for enforcement of orders made in cases involving violations of the unfair labor practice provisions of the Act. NLRA $\S 10(\mathrm{e}), 29$ U.S.C. $\$ 160$ (e) (1964).

5. Where a legitimate Board investigation is under way, the Board is given the power to petition courts for orders enforcing its subpenas under NLRA $\$ 11(2)$, 29 U.S.C. \$161(2) (1964).

Exceptional circumstances, as has already been noted, allow resort to the general provisions of $\$ 1337$. See notes 46-49 supra and accompanying text.

59 See NLRA \& 8(a) (1), 29 U.S.C. § 158(a) (1) (1964).

60 S. REP. No. 573, 74th Cong., 1st Sess. 8 (1934). 